\title{
A simple and inexpensive procedure for low valent copper mediated benzylation of aldehydes in wet medium
}

\author{
Akhil Kr.Dubey, Dibakar Goswami, and Angshuman Chattopadhyay* \\ Bio-Organic Division, Bhabha Atomic Research Centre, \\ Mumbai-400 085, India \\ E-mail: achat@apsara.barc.ernet.in
}

\begin{abstract}
An operationally simple, inexpensive and efficient procedure for benzylation of aldehydes in wet medium has been developed that was mediated with low valent copper, prepared in situ through spontaneous reduction of $\mathrm{CuCl}_{2}-2 \mathrm{H}_{2} \mathrm{O}$ with magnesium in situ. Notably, copper mediated benzylation of $\mathbf{3 h}$ took place with good syn selectivity that was opposite to that for the corresponding Grignard addition. Finally, homobenzyl alcohol 5a was elegantly transformed into a known protease inhibitor synthon $\mathbf{I}$.
\end{abstract}

Keywords: benzylation, wet medium, bimetal redox strategy, syn-selectivity, (R)-2,3cyclohexylideneglyceraldehyde, $\alpha$-chelate cyclic model, protease inhibitor synthon

\section{Introduction}

Carbon-carbon bond formation is the essence of organic synthesis. In this regard, metal mediated carbon-carbon bond forming reactions is always treated as a useful strategy in organic synthesis. Consequently, over the ages exploration of the potentials of various metals to promote various types of Barbier type addition of organic halides to electrophiles has become a topic of wide attention. ${ }^{1}$ It is well known that to mediate any $\mathrm{C}-\mathrm{C}$ bond forming reaction, obtaining a metal in suitably active form under the reaction condition is of high importance. Furthermore, apart from its nature, the method of its activation plays a good role in directing the stereo-selectivity in the case of asymmetric additions. In this perspective, there is a scope for studying the potential of different metals in their various active forms to promote Barbier type additions to carbonyls.

Benzylation of aldehydes is an important type of Barbier type carbon-carbon bond forming reactions in organic synthesis. The homobenzylic alcohols produced from such reactions due to their functional richness are amenable for versatile applications in organic synthesis. ${ }^{2}$ A very common procedure traditionally practiced to prepare homobenzylic alcohols is via Grignard addition of benzylic bromides to carbonyls which can only be performed in anhydrous reaction media. In addition, some other strategies were reported in earlier days to prepare homobenzylic 
alcohols involving hydroboration of 1-aryl-alkenes, ${ }^{3}$ solvolyses of sulfonates obtained from aromatic bridged hydrocarbons ${ }^{4}$ and regio-selective hydrogenation of aromatic epoxides in recent years ${ }^{5}$ etc. Recently, in view of current attention on performing many organic reactions in environmentally friendly aqueous media, ${ }^{6}$ considerable attention has been focused on performing Barbier type additions of benzyl bromide to aldehydes mediated with metals viz Cd obtained from tri-metal system, ${ }^{7 \mathrm{a}} \mathrm{Zn}$ in presence of $\mathrm{Ag}$ catalyst, ${ }^{7 \mathrm{~b}}$ etc. In a recently reported approach, silver catalysed Mn mediated Barbier type benzylation can be performed in highly anhydrous THF. ${ }^{8}$

We present here a very simple and practically viable procedure for benzylation of aldehydes in wet solvent. Our strategy was based on judicious application of bimetal redox strategy (Scheme 1) ${ }^{9}$ to effect this reaction in wet condition. ${ }^{9}$ Earlier, this approach was applied to perform two C-C bond forming reactions successfully viz allylation ${ }^{9 a, b}$ and Reformatsky reaction $^{9 \mathrm{c}}$ in distilled THF. Interestingly, to carry out the afore-mentioned allylation and Reformatsky reaction through application of bimetal redox strategy, the low valent metal mediators needed to be prepared in situ by reduction of their salts with different reducing metals viz $\mathrm{Zn}^{9 \mathrm{a}, \mathrm{b}}$ and $\mathrm{Mg}^{9 \mathrm{c}}$ respectively. From these two instances, it could be suggested that the choice of a suitable combination of reducing metal and reducible salt is of high importance regarding the efficacy of a C-C bond forming reaction in moist condition according to this bimetal redox strategy (Scheme 1). However, all the above mentioned C-C bond forming reactions ${ }^{9 a-c}$ could be performed efficiently in distilled THF whose inherent moisture content ${ }^{10}$ distinctly favored such organometallation (as shown in Scheme 1).

$$
\begin{gathered}
\mathrm{M}_{1} \mathrm{X}+\mathrm{M}_{2} \longrightarrow \mathrm{M}_{2} \mathrm{X}+\mathrm{M}_{1} \text { (low valent) } \\
\mathrm{M}_{1} \mathrm{X}, \mathrm{CuCl}_{2} \cdot 6 \mathrm{H}_{2} \mathrm{O} ; \mathrm{FeCl}_{3} ; \mathrm{M}_{2}, \mathrm{Zn} ; \mathrm{Mg} \\
\mathrm{BrCH}_{2} \mathrm{Ph}+\mathrm{M}_{1} \longrightarrow \underset{2}{\mathrm{BrM}_{1} \mathrm{CH}_{2} \mathrm{Ph}} \\
\mathbf{1}
\end{gathered}
$$
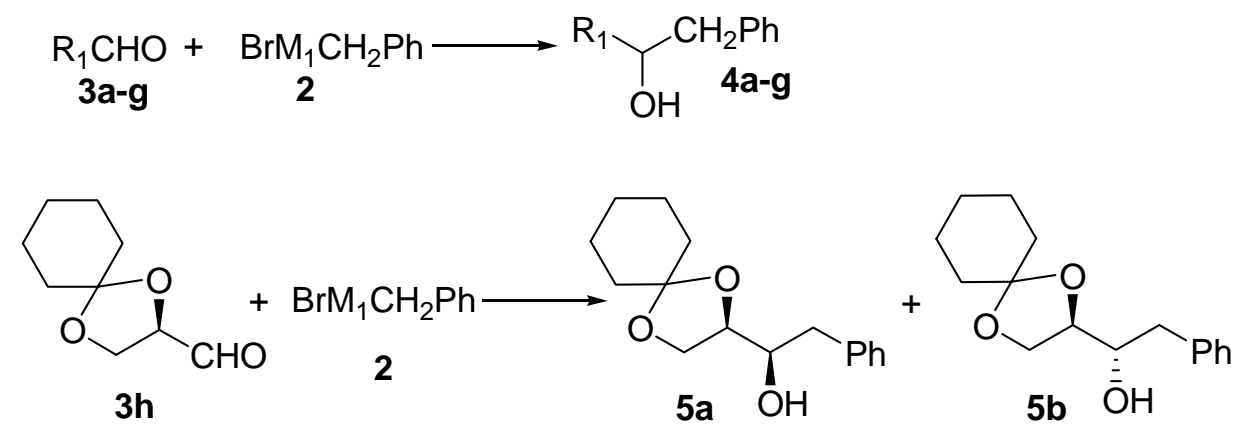

Scheme 1. Low valent metal mediated benzylation of aldehydes. 
We once again attempted to explore the scope of this strategy for benzylation of aldehydes in distilled THF. Based on our earlier success, ${ }^{9 a-c}$ we decided to investigate on the efficacy of the present reaction using all four possible combinations between two reducible salts $\left(\mathrm{M}_{1} \mathrm{X}\right)$, viz $\mathrm{FeCl}_{3}\left(97 \%\right.$, Aldrich) and $\mathrm{CuCl}_{2}-2 \mathrm{H}_{2} \mathrm{O}$ (Aldrich) and two reducing metals $\left(\mathrm{M}_{2}\right)$ viz $\mathrm{Zn}$ dust (SRL India) and magnesium turning (SRL India). Three classes of aldehyde substrates were chosen, viz aliphatic (3a-c, Aldrich), aromatic (3d-g, Aldrich) and a chiral $\mathbf{3 h}{ }^{11}$ with a view to exploring the generality of this strategy. (Scheme 1) In all these heterogeneous reactions, an aldehyde was treated with excess amounts of reagents viz benzyl bromide (Aldrich), salt $\mathrm{M}_{1} \mathrm{X}$ and reducing metal $\mathrm{M}_{2}$ to ensure their smooth progress.

Table-1. Low valent $\mathrm{Cu}$ mediated Benzylation reaction of aldehydes

\begin{tabular}{|c|c|c|c|c|c|c|}
\hline Entry & $\mathrm{R}_{1}$ of Aldehyde & $\begin{array}{c}\text { Aldehyde: } \\
\mathrm{Mg}): \mathrm{CuCl}_{2}, 2 \mathrm{H}_{2} \mathrm{O}: \\
\mathrm{PhCH}_{2} \mathrm{Br}\end{array}$ & $\begin{array}{l}\text { Time } \\
\text { hr }\end{array}$ & product & $\begin{array}{l}\% \\
\text { yield }\end{array}$ & $\begin{array}{l}\text { Product } \\
\text { ratio }\end{array}$ \\
\hline $\mathrm{a}$ & $n-\mathrm{C}_{6} \mathrm{H}_{13}$ 3a & $1.0: 4.0: 4.0: 1.5$ & 18 & $4 a^{a}$ & 61.8 & \\
\hline $\mathrm{b}$ & $n-\mathrm{C}_{9} \mathrm{H}_{19} \mathbf{3 b}$ & $1.0: 4.0: 4.0: 1.5$ & 16 & $4 b^{b}$ & 64.4 & \\
\hline $\mathrm{c}$ & $n-\mathrm{C}_{13} \mathrm{H}_{27} 3 \mathrm{c}$ & $1.0: 4.0: 4.0: 1.5$ & 16 & $4 c$ & 57.8 & \\
\hline d & $\mathrm{C}_{6} \mathrm{H}_{5}$ 3d & $1.0: 3.0: 3.0: 1.5$ & 9 & $4 d^{\mathrm{a}}$ & 71.7 & \\
\hline e & $3-\mathrm{MeOC}_{6} \mathrm{H}_{5}$ 3e & $1.0: 3.0: 3.5: 1.5$ & 8 & $4 e$ & 73.8 & \\
\hline $\mathrm{f}$ & $4-E t-\mathrm{C}_{6} \mathrm{H}_{5} \mathbf{3 f}$ & $1.0: 3.0: 3.5: 1.5$ & 7 & $4 f$ & 70.7 & \\
\hline g & $4-\mathrm{Cl}-\mathrm{C}_{6} \mathrm{H}_{5} \mathbf{3 g}$ & $\begin{array}{c}1.0: 4.0: \\
4.0: 1.5\end{array}$ & 11 & $4 g^{a}$ & 68.9 & \\
\hline $\mathrm{h}$ & $\begin{array}{c}(R)-2,3- \\
\text { cyclohexylideneglyceral } \mathbf{3 h}\end{array}$ & $1.0: 7.0: 7.0: 2.5$ & 20 & $\begin{array}{c}5 a \& \\
5 b\end{array}$ & 68.4 & $\begin{array}{c}\mathbf{5 a}: \mathbf{5 b}:: \\
80: 20^{\mathrm{c}}\end{array}$ \\
\hline
\end{tabular}

${ }^{a}$ The compounds were characterized from their spectral data (reference $7 \mathrm{~b}$ )

${ }^{b}$ the compound was characterized from its spectral data (reference 12)

${ }^{\mathrm{c}}$ The ratio was determined from ${ }^{13} \mathrm{C}$ NMR of the product (reference 13)

\section{Results and Discussion}

Using zinc as reducing metal in combination with either of the metal salts $\left(\mathrm{Zn} / \mathrm{CuCl}_{2}-2 \mathrm{H}_{2} \mathrm{O}\right.$ or $\mathrm{Zn} / \mathrm{FeCl}_{3}$ ), was found to be ineffective for reactions with all the aldehydes 3a-h. Likewise, using the combination of $\mathrm{Mg} / \mathrm{FeCl}_{3}$ also did not give any encouraging sign of progress with any of these aldehydes. However, to our great delight the combination of $\mathrm{Mg} / \mathrm{CuCl}_{2}, 2 \mathrm{H}_{2} \mathrm{O}$ was found to be highly favorable for benzylation of all the aldehydes producing corresponding homobenzylic alcohols in good yields. (Table 1 and Scheme 1, 4a-g from 3a-g, 5 from 3h). Among the successful reactions, aromatic aldehydes reacted more efficiently at comparatively faster rates (entries d-g, Table 1) with respect to aliphatic ones. Benzylation with $\mathbf{3 h}$ (entry h, 
Table 1) took place to produce homobenzylic alcohol 5 in reasonably good yield (68.4\%) and syn selectivity (syn-5a : anti-5b $80: 20$ ). Owing to the inseparability of the diastereomers $\mathbf{5 a} / \mathbf{5 b}$ by column chromatography, their ratio could be assayed from ${ }^{13} \mathrm{C}$ NMR spectrum ${ }^{13}$ of this mixture. The predominant formation of syn-5a for (entries s, Table 1) gave evidence of the fact that all the reactions took place via the addition of the corresponding organocopper reagents 2 (Scheme 1) through $\alpha$-chelate cyclic model. ${ }^{14}$ It is worth mentioning that the corresponding benzyl-Grignard addition to 5 a took place with lower yield (43.8 \%) compared to the organo-copper addition done above and with anti selectivity (syn-5a : anti-5b : $35: 65$, vide ${ }^{13}$-C NMR supporting information $)^{13}$.
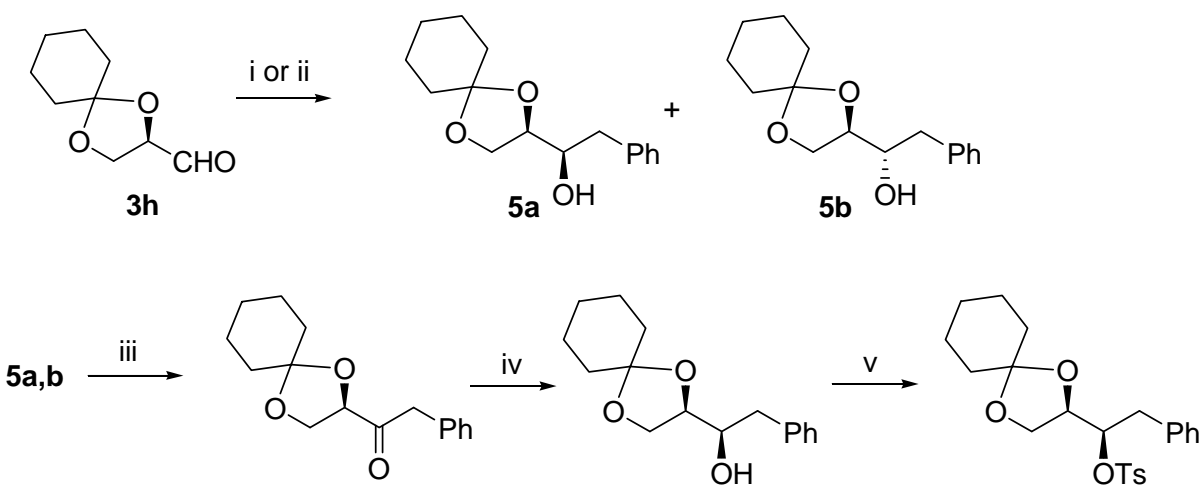

6

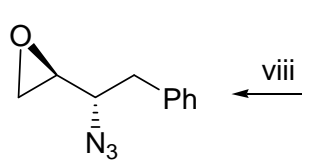

I
$5 a$

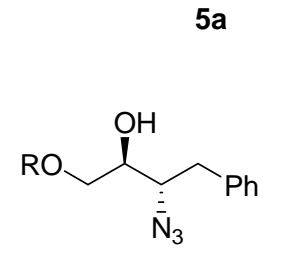

9, $\mathrm{R}=\mathrm{H}$ $10, R=$ Tos

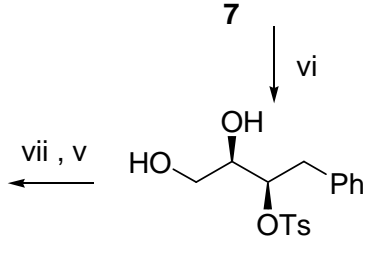

8

i) $\mathrm{PhCH}_{2} \mathrm{MgBr}$, THF, rt; ii) Mg / $\mathrm{CuCl}_{2}, 2 \mathrm{H}_{2} \mathrm{O}$, THF iii) PCC, $\mathrm{CH}_{2} \mathrm{Cl}_{2}$; iv) K-selectride, $-78^{\circ} \mathrm{C}$, THF; v) TosCl, Py, $0^{\circ} \mathrm{C}$; vi) Aq $\mathrm{CF}_{3} \mathrm{COOH}, 0^{\circ} \mathrm{C}$; vii) $\mathrm{NaN}_{3}$, DMF, heat; viii) $\mathrm{K}_{2} \mathrm{CO}_{3}, \mathrm{MeOH}$.

Scheme 2. Synthesis of target molecule I.

The proportion of syn-5a in this distereoisomeric mixture has been increased (Scheme 2) following a known oxidation-reduction protocol. ${ }^{15}$ Thus, PCC oxidation of the diastereoismeric mixture 5a,b to afford ketone $\mathbf{6}$ which on reduction with K-selectride yielded syn-5a with $99 \%$ stereo-selectivity. ${ }^{13}$ Tosylation of $\mathbf{5 a}$, followed by deketalization of the resulting tosylate $\mathbf{7}$ in acidic condition afforded crude diol 8 which on treatment with $\mathrm{NaN}_{3}$ afforded $\mathbf{9}^{16 \mathrm{~b}, \mathrm{de}, \mathrm{e}} 17$ in good yield. Monotosylation of the primary hydroxyl of $\mathbf{9}$ and base treatment of the resulting tosylate 10 yielded azido epoxide I, a key synthon ${ }^{16}$ of a HIV protease inhibitor. (Scheme 2) Our synthesized compound I were characterized from the conformity of its physical, spectral and optical data with the reported ones. ${ }^{16}$ 
Thus, a very mild and efficient procedure for benzylation of aldehydes has been developed. The novelty of the approach was due to smooth exploitation of the spontaneous bimetal redox reaction in an environmentally benign wet condition between commercially available chemicals, $\mathrm{Mg}$ and $\mathrm{CuCl}_{2}, 6 \mathrm{H}_{2} \mathrm{O}$ in THF to effect this important carbon-carbon bond formation. The inexpensiveness, practical viability and good yields with varied types of aldehyde substrates (3a$\mathbf{h}$, Table 1) associated with this non hazardous procedure are of immense significance regarding its overall efficacy. Finally, as a representative application of the this work, benzylation product of $3 \mathbf{h}$ has been judiciously exploited in a simple and straight forward manner (Scheme 2) to prepare a key synthon $\mathbf{I}^{16}$ of a protease inhibitor.

\section{Experimental Section}

General. Chemicals used as starting materials are commercially available and were used without further purification. All solvents used for chromatography and extraction were distilled twice at atmospheric pressure prior to use. Moist THF was distilled once prior to use in all bimetal redox reactions. For anhydrous reactions, THF was dried by heating over $\mathrm{LiAlH}_{4}$. IR spectra were recorded with a Perkin-Elmer 837 spectrophotometer. ${ }^{1} \mathrm{H}$ and ${ }^{13} \mathrm{C}$ NMR spectra were scanned with a Bruker Ac-200 (200 MHz) instrument in $\mathrm{CDCl}_{3}$. Chemical shifts are expressed in ppm downfield from TMS Optical rotations were measured with a JASCO DIP-360 polarimeter; $[\alpha]_{D}$ values are given in units of $10^{-1} \mathrm{deg} \mathrm{cm}^{-3} \mathrm{~g}^{-1}$.

\section{General procedure of low valent metal mediated benzylation reaction}

To a well stirred mixture of aldehyde $3(0.01 \mathrm{~mol})$, benzyl bromide 2 ( $2.57 \mathrm{~g}, 0.015 \mathrm{~mol}$ for 3a-h and $4.28 \mathrm{~g}$ for $3 \mathbf{i})$ and $\mathrm{CuCl}_{2}-2 \mathrm{H}_{2} \mathrm{O}(6.8 \mathrm{~g}, 0.04 \mathrm{~mol}$ for 3a-c, g; $5.1 \mathrm{~g}, 0.03 \mathrm{~mol}$ for 3d; 5.95, $0.035 \mathrm{~mol}$ for $3 \mathbf{e}, \mathbf{f} ; 11.9 \mathrm{~g}, 0.07 \mathrm{~mol}$ for $3 \mathbf{h})$ or $\mathrm{FeCl}_{3}(6.48 \mathrm{~g}, 0.04 \mathrm{~mol}$ for $3 \mathbf{a}-\mathbf{c}, \mathbf{g} ; 4.86 \mathrm{~g}$, $0.03 \mathrm{~mol}$ for 3d; 5.66, $0.035 \mathrm{~mol}$ for 3e,f ; $8.1 \mathrm{~g}, 0.05 \mathrm{~mol}$ for $3 \mathbf{h}$ ) in THF (100 mL) was added $\mathrm{Mg}$ turnings (960 mg, $0.04 \mathrm{~mol}$ for 3a-c, g; $720 \mathrm{mg}, 0.03 \mathrm{~mol}$ for 3d-f; $1.68 \mathrm{~g}, 0.07 \mathrm{~mol}$ for $3 \mathbf{h}$ ) or $\mathrm{Zn}$ dust (2.6 g, $0.04 \mathrm{~mol}$ for 3a-c, g; $1.95 \mathrm{~g}, 0.03 \mathrm{~mol}$ for $3 \mathbf{d}-\mathbf{f} ; 3.25 \mathrm{~g}, 0.05 \mathrm{~mol}$ for $3 \mathbf{h}$ ) in one lot. The mixture was stirred at the ambient temperature for the period as shown in Table. No reaction was found to take place in the cases with $\mathrm{Zn} / \mathrm{CuCl}_{2}, 2 \mathrm{H}_{2} \mathrm{O}$ or $\mathrm{Zn} / \mathrm{FeCl}_{3}$ or $\mathrm{Mg} / \mathrm{FeCl}_{3}$ (vide TLC). For reactions with $\mathrm{Mg} / \mathrm{CuCl}_{2}, 2 \mathrm{H}_{2} \mathrm{O}$, benzylation product was produced for all cases (vide TLC). The reaction mixture was then treated successively with water $(50 \mathrm{~mL})$ and EtOAc $(100 \mathrm{~mL})$, stirred for $10 \mathrm{~min}$ more and then filtered. The filtrate was treated with $2 \%$ aqueous $\mathrm{HCl}$ to dissolve a little amount of suspended particles. The organic layer was separated. The aqueous layer was extracted with EtOAc. The combined organic layer was washed with water, brine and then dried. Solvent removal and column chromatography of the residue (silica gel, 0-20\% EtOAc in petroleum ether) afforded the desired benzylation products in pure form.

1-Phenylpentadecan-2-ol (4c). ${ }^{1} \mathrm{H}$ NMR $\left(\mathrm{CDCl}_{3}\right): \delta 0.97$ (bt, 3H), 1.2-1.6 (m, 24H), 1.7 (bs, 1H), $2.73(\mathrm{dd}, J=13.4,8.4 \mathrm{~Hz}, 1 \mathrm{H}), 2.93$ (dd, $J=13.6,4.4 \mathrm{~Hz}, 1 \mathrm{H}), 3.8-3.9(\mathrm{~m}, 1 \mathrm{H}), 7.2-7.5$ 
(m, 5H). ${ }^{13} \mathrm{C} \mathrm{NMR}\left(\mathrm{CDCl}_{3}\right)$ : 14.1, 22.6, 25.7, 29.3, 29.6, 31.9, 36.8, 44.0, 72.6, 126.4, 128.5, 129.4, 138.6. Anal. Calcd for $\mathrm{C}_{21} \mathrm{H}_{36} \mathrm{O}: \mathrm{C}, 82.83$; H, 11.91. Found: C, 82.64; H, 12.14 .

1-(3-Methoxyphenyl)-2-phenylethanol (4e). ${ }^{1} \mathrm{H}$ NMR $\left(\mathrm{CDCl}_{3}\right): \delta 1.98(\mathrm{bs}, 1 \mathrm{H}), 3.10(\mathrm{~m}, 2 \mathrm{H})$, $3.8(\mathrm{~s}, 3 \mathrm{H}), 4.97(\mathrm{dd}, J=8.0,5.2 \mathrm{~Hz}, 1 \mathrm{H}), 6.9-7.2(\mathrm{~m}, 3 \mathrm{H}), 7.3-7.4(\mathrm{~m}, 6 \mathrm{H}) .{ }^{13} \mathrm{C} \mathrm{NMR}\left(\mathrm{CDCl}_{3}\right)$ : 45.5, 54.8, 74.8, 111.0, 112.8, 118.0, 126.1, 128.0, 129.0, 129.2, 137.8, 145.3, 159.2.

Anal. Calcd for $\mathrm{C}_{15} \mathrm{H}_{16} \mathrm{O}_{2}$ : C, 78.92; H, 7.06. Found: C, 78.98; H, 6.80.

1-(4-Ethylphenyl)-2-phenylethanol (4f). ${ }^{1} \mathrm{H} \mathrm{NMR}\left(\mathrm{CDCl}_{3}\right): \delta 1.43(\mathrm{t}, J=7.6 \mathrm{~Hz}, 3 \mathrm{H}), 2.26(\mathrm{~s}$, $1 \mathrm{H}), 2.84$ (q, $J=7.8 \mathrm{~Hz}, 2 \mathrm{H}), 3.16(\mathrm{~m}, 2 \mathrm{H}), 5.0(\mathrm{~m}, 1 \mathrm{H}), 7.3-7.5(\mathrm{~m}, 9 \mathrm{H}) .{ }^{13} \mathrm{C} \mathrm{NMR}\left(\mathrm{CDCl}_{3}\right)$ : $15.5,28.4,45.8,75.0,125.8,126.4,127.7,128.3,129.4,138.2,141.0,143.5$.

\section{Addition of benzyl Grignard to $3 \mathrm{~h}$}

A solution of benzyl bromide (3.42 g, 0.02 mole) in $\mathrm{Et}_{2} \mathrm{O}(50 \mathrm{~mL})$ was added drop wise over a period of $2 \mathrm{~h}$ to a stirred suspension of $\mathrm{Mg}(600 \mathrm{mg}, 0.025 \mathrm{~mole})$ in $(50 \mathrm{~mL})$ at room temperature. The mixture was stirred for $3 \mathrm{~h}$ more at room temperature to produce benzylGrignard and cooled to $-40{ }^{\circ} \mathrm{C}$. To it, a solution of $3 \mathbf{h}(1.70 \mathrm{~g}, 0.01 \mathrm{~mol})$ in $\mathrm{Et}_{2} \mathrm{O}(50 \mathrm{~mL})$ was added over a period of 1 $\mathrm{h}$. The mixture was stirred for $2 \mathrm{~h}$ at $-40^{\circ} \mathrm{C}$, gradually brought to room temperature and stirred for $3 \mathrm{~h}$ more. Saturated aqueous $\mathrm{NH}_{4} \mathrm{Cl}(10 \mathrm{~mL})$ was added to it. The mixture was extracted with EtOAc. The combined organic extract was washed with water, brine and dried. Solvent removal under reduced pressure and column chromatography of the residue (silica gel, 0-20\% EtOAc in petroleum ether) afforded the pure $5(1.15 \mathrm{~g}, 43.8 \%)$ containing an inseparable mixture of diastereomers (5a,b) (syn 5a: anti 5b : 35:65, as determined from ${ }^{13}$-C-NMR (supporting information) of the mixture (reference 13)).

(3R)-3,4-O-Cyclohexylidene-2-oxo-1-phenylbutane-3,4-diol (6). To a stirred suspension of pyridinium chlorochromate $(2.6 \mathrm{~g}, 0.012 \mathrm{~mol})$ in $\mathrm{CH}_{2} \mathrm{Cl}_{2}(60 \mathrm{~mL})$ was added a solution of 5a, $5 \mathbf{b}$ $(2.1 \mathrm{~g}, 0.008 \mathrm{~mol})$. The mixture was stirred at ambient temperature for nearly $3 \mathrm{~h}$ till the disappearance of the starting material (TLC), diluted with diethyl ether $(50 \mathrm{~mL})$ and filtered through a column of celite. Solvent removal of the filtrate under reduced pressure and colum chromatography of the residue (silica gel, 0-15\% EtOAc-petroleum ether) afforded pure 6 (1.56 $\mathrm{g}, 74.3 \%) .[\alpha]_{\mathrm{D}}{ }^{26} 10.40\left(\mathrm{c} 2.0, \mathrm{CHCl}_{3}\right)_{2}{ }^{1} \mathrm{H} \mathrm{NMR}\left(\mathrm{CDCl}_{3}\right): \delta 1.2-1.6(\mathrm{~m}, 10 \mathrm{H}), 3.7-4.3(\mathrm{~m}, 4 \mathrm{H})$, 4.4-4.5 (m, 1H), 7.1-7.3 (m, 5H). ${ }^{13} \mathrm{C} \mathrm{NMR}\left(\mathrm{CDCl}_{3}\right): 23.6,23.9,24.9,34.3,35.6,45.3,66.0$, 79.4, 111.6, 126.8, 128.4, 129.6, 133.2, 207.9. Anal. Calcd for $\mathrm{C}_{16} \mathrm{H}_{20} \mathrm{O}_{3}$ : C, 73.81; H, 7.74. Found: C, 73.99; H, 7.55.

(2R,3R)-3,4-O-Cyclohexylidene-1-phenylbutane-2,3,4-triol (5a). Following the procedure reported earlier, ${ }^{15}$ a solution of $6(1.4 \mathrm{~g}, 5.38 \mathrm{mmol})$ in THF $(30 \mathrm{~mL})$ was reduced with $\mathrm{K}$ selectride $(5.5 \mathrm{~mL}$ of 1 molar in THF, $5.5 \mathrm{mmol})$ at $-78{ }^{\circ} \mathrm{C}$. Similar work up and column chromatography (silica gel, 0-20\% EtOAc-petroleum ether) of the crude product afforded 5a (1.32 g, 93.6\%). [ $\alpha]_{\mathrm{D}}{ }^{25} 9.12\left(\mathrm{c} 1.2, \mathrm{CHCl}_{3}\right) ;{ }^{1} \mathrm{H} \mathrm{NMR}\left(\mathrm{CDCl}_{3}\right): \delta 1.2-1.6(\mathrm{~m}, 10 \mathrm{H}), 2.40(\mathrm{bs}, 1 \mathrm{H})$, 2.7-2.8 (m, 2H), 3.64-3.78 (m, 2H), 3.87-4.0 (m, 2H), 7.2-7.3 (m, 5H). ${ }^{13} \mathrm{C} \mathrm{NMR}\left(\mathrm{CDCl}_{3}\right)$ : 23.6, 23.9, 25.0, 34.6, 36.1, 40.1, 65.5, 72.9, 77.4, 109.7, 126.3, 128.3, 129.2, 137.6 Anal. Calcd for $\mathrm{C}_{16} \mathrm{H}_{22} \mathrm{O}_{3}$ : C, 73.25; H, 8.45. Found: C, 73.38; H, 8.62. 
(2R, 3R)- 3,4-O-Cyclohexylidene-2-O-p-toluenesulphonyl-1-phenyl-butane-2,3,4-triol (7). To a cooled $\left(0^{\circ} \mathrm{C}\right)$ solution of $5 a(786 \mathrm{mg}, 3 \mathrm{mmol})$ in Pyridine $(4 \mathrm{~mL})$ containing DMAP $(50 \mathrm{mg})$ was slowly added a $p$-toluenesulfonylchloride $(575 \mathrm{mg}, 3 \mathrm{mmol})$. The mixture was stirred at $0{ }^{\circ} \mathrm{C}$ for $6 \mathrm{~h}$. After the reaction was complete (monitored with TLC), it was quenched by addition was water and extracted with $\mathrm{CHCl}_{3}$. The organic layer was washed successively with $5 \%$ aqueous $\mathrm{HCl}$, water, brine and then dried. Solvent removal under reduced pressure, and column chromatography of the residue (silica gel, 0-20\% EtOAc-petroleum ether) afforded 7 (1.14 g, 91.1\%). $[\alpha]_{\mathrm{D}}{ }^{25} 32.8\left(\mathrm{c} 3.2, \mathrm{CHCl}_{3}\right){ }^{1} \mathrm{H} \mathrm{NMR}\left(\mathrm{CDCl}_{3}\right): \delta 1.4-1.6(\mathrm{~m}, 10 \mathrm{H}), 2.39(\mathrm{~s}, 3 \mathrm{H}), 2.78(\mathrm{q}, J$ $=7.2 \mathrm{~Hz}, 1 \mathrm{H}), 3.10(\mathrm{dd}, J=13.8,6.4 \mathrm{~Hz}, 1 \mathrm{H}), 3.7-3.9(\mathrm{~m}, 2 \mathrm{H}), 4.2(\mathrm{~m}, 1 \mathrm{H}), 4.6(\mathrm{~m}, 1 \mathrm{H}), 7.04-$ $7.25(\mathrm{~m}, 7 \mathrm{H}), 7.58(\mathrm{~d}, J=8.2 \mathrm{~Hz}, 2 \mathrm{H}) .{ }^{13} \mathrm{C} \mathrm{NMR}\left(\mathrm{CDCl}_{3}\right): 21.3,23.5,23.6,24.9,34.2,35.4,36.5$, $64.4,74.1,82.1,110.0,126.4,127.4,128.2,129.3,129.4,133.3,135.5,144.2$. Anal. Calcd for $\mathrm{C}_{23} \mathrm{H}_{28} \mathrm{O}_{5} \mathrm{~S}: \mathrm{C}, 66.32 ; \mathrm{H}, 6.72 ; \mathrm{S}, 7.69$. Found: C, 66.14; H, 6.65; S,7.89.

(2S, 3R)- 2-Azido -1-phenyl-butane-3,4-diol (9). To a cooled $\left(0^{\circ} \mathrm{C}\right)$ solution of 7 (832 $\mathrm{mg}, 2$ mmol) in $\mathrm{CH}_{2} \mathrm{Cl}_{2}(40 \mathrm{~mL})$ was added $90 \%$ aqueous $\mathrm{CF}_{3} \mathrm{COOH}$ solution $(5 \mathrm{~mL})$. The mixture was stirred for $4 \mathrm{~h}$ till the total disappearance of starting material (TLC), diluted with water (100 $\mathrm{mL})$ and extracted with $\mathrm{CHCl}_{3}$. the combined organic extract was washed thoroughly with water and brine. Solvent removal under reduced pressure afforded the crude residue of $\mathbf{8}$ which was taken in DMF $(30 \mathrm{~mL})$. The solution was treated with $\mathrm{NaN}_{3}(163 \mathrm{mg}, 2.5 \mathrm{mmol})$ and heated $\left(80{ }^{\circ} \mathrm{C}\right)$ along with stirring for $4 \mathrm{~h}$. Most of DMF in the mixture was distilled off under reduced pressure and the residue was taken in water, extracted with EtOAc. The combined organic extract was washed successively with water, brine and dried. Solvent removal under reduced pressure and column chromatography of the residue (silica gel, 0-15\% EtOAc-petroleum ether) afforded 9 (308 mg, 74.1\%) as a white solid. Mp 80-81 ${ }^{\circ} \mathrm{C}$, lit ${ }^{16 \mathrm{e}} \mathrm{mp} 80-82^{\circ} \mathrm{C}$; $[\alpha]_{\mathrm{D}}{ }^{25} 30.2$ (c 1.8, $\mathrm{CHCl}_{3}$ ); $\operatorname{lit}^{16 \mathrm{~b}}[\alpha]_{\mathrm{D}}{ }^{25} 30.6\left(\mathrm{c} 2.0, \mathrm{CHCl}_{3}\right) ;{ }^{1} \mathrm{H}$ NMR $\left(\mathrm{CDCl}_{3}\right): \delta 1.26(\mathrm{bs}, 2 \mathrm{H}), 2.72-2.83(\mathrm{~m}, 1 \mathrm{H}), 2.92-3.09$ $(\mathrm{m}, 1 \mathrm{H}), 3.6-3.8(\mathrm{~m}, 4 \mathrm{H}), 7.29(\mathrm{~m}, 5 \mathrm{H}) .{ }^{13} \mathrm{C} \mathrm{NMR}\left(\mathrm{CDCl}_{3}\right): 36.9,63.1,65.5,73.0,126.9,128.6$, 129.2, 137.2.

2S-[1(S)-Azido-2-phenylethyl]oxirane (I). To a cooled $\left(0{ }^{\circ} \mathrm{C}\right)$ solution of $9(207 \mathrm{mg}, 1 \mathrm{mmol})$ in pyridine $(4 \mathrm{~mL})$ was slowly added $p$-toluenesulfonylchloride $(200 \mathrm{mg}, 1.05 \mathrm{mmol})$. The mixture was stirred overnight at $0{ }^{\circ} \mathrm{C}$. After the reaction was complete (monitored with TLC), it was quenched by addition was water and extracted with $\mathrm{CHCl}_{3}$. The organic layer was washed successively with $5 \%$ aqueous $\mathrm{HCl}$, water, brine and then dried. Solvent removal under reduced pressure afforded the residue containing 10 which was taken in $\mathrm{MeOH}(30 \mathrm{~mL})$. The solution was mixed with $\mathrm{K}_{2} \mathrm{CO}_{3}(500 \mathrm{mg}, 3.6 \mathrm{mmol})$ and stirred for $4 \mathrm{~h}$ at room temperature. Excess $\mathrm{MeOH}$ was evaporated under reduced pressure. The residue was dissolved in EtOAc and washed successively with water, brine and then dried. Solvent removal under reduced pressure and colum chromatography of the residue (silica gel, 0-10\% EtOAc-petroleum ether) afforded I (145 $\mathrm{mg}, 77.1 \%)$. $[\alpha]_{\mathrm{D}}{ }^{26} 12.9\left(\mathrm{c} 1.0, \mathrm{CHCl}_{3}\right) ; \operatorname{lit}^{16 \mathrm{~d}}[\alpha]_{\mathrm{D}}{ }^{25} 12.9$ (c 1.15, $\left.\mathrm{CHCl}_{3}\right) ;{ }^{1} \mathrm{H} \mathrm{NMR}\left(\mathrm{CDCl}_{3}\right): \delta$ 2.84-2.96 (m, 3H), $3.05(\mathrm{~d}, J=4.6 \mathrm{~Hz}, 1 \mathrm{H}), 3.11-3.17(\mathrm{~m}, 1 \mathrm{H}), 3.64-3.71(\mathrm{~m}, 1 \mathrm{H}), 7.33-7.47$ (m, 5H). ${ }^{13} \mathrm{C} \mathrm{NMR}\left(\mathrm{CDCl}_{3}\right): 38.2,45.1,53.0,63.5,126.9,128.5,129.3,136.5$. 


\section{References}

1. (a) Alcaide, B.; Almendros, P.; Campo, T. M. Eur. J. Org. Chem. 2008, 2628. (b) Zhang, WC.; Li, C-J. J. Org. Chem.. 1999, 64, 3230. (c) Wessjohann, L. A.; Schmidt, G.; Schrekker, H. S.; (d) Fürstner, A. Angew. Chem. Int. Ed. Engl. 1993, 32, 164. (e) Rieke, R. D. Science 1989, 246, 1260. f) Erdik, E. Tetrahedron, 1987, 43, 2203.

2. (a) Chowdhury, P. K.; Almena, J.; Foubelo, F.; Yus, M. Tetrahedron, 1997, 53, 17373. (b) Thangarasa, R.; Green, J. R.; Nadasdit, T. J. Chem. Soc. Chem. Comm. 1994, 501.

3. Allred, E. A.; Sonnenberg, J.; Winstein, S. J. Org. Chem.. 1960, 25, 26 and references cited therein.

4. (a) Tanida, H.; Ishitobi, H.; Irie T.; Tsushima, T. J. Am. Chem. Soc. 1969, 91, 4512. (b) Tanida, H.; Ysuji, T.; Ishitobi, H. J. Am. Chem. Soc. 1964, 86, 4904.

5. Ley, S. V.; Stewart-Liddon, A. J. P.; Pears, D.; Perri, R. H.; Treacher, K. Beilst. J. Org. Chem. 2006, 2, 1.

6. (a) Li, C. J. Chem. Rev. 2005, 105, 3095 and references cited therein. (b) Li, C. J.; Chan, T. H. Organic reactions in Aqueous Media; Wiley: New York, 1997. 9c) Grieco, P. Ed. Organic Reactions in Water; Chapman \& Hall: London, 1998. (d) Mulzer, J.; Attenbach,; Braun, M.; Reissig, H. Organic Synthesis Highlights; VCH:Weinheim, 1991; pp 71. (e) Petrier, C.; Luche, J. L. J. Org. Chem. 1985, 50, 910. (f) Li, C. J. Chem. Rev. 1993, 93, 2023 and references cited therein.

7. (a)Zhou, C.; Jiang, J.; Zhou, Y.; Miao, Q.; Wang, Z. Lett. Org. Chem. 2005, 2, 61. (b) Biebar, L. W.; Storch, E. C.; Malvestiti, I.; Da Silva, M. F. Tetrahedron Lett. 1998, 39, 9393.,

8. Barczak, N. T.; Jarvo, E. R. Eur. J. Chem. 2008, 5507.

9. (a) Chattopadhyay, A.; Goswami, D.; Dhotare, B. Tetrahedron Lett. 2006, 47, 4701. (b) Dhotare, B; Chattopadhyay, A. Tetrahedron Asymm. 2009, 20, 2007. 9c) Chattopadhyay, A.; Dubey, A. K. J. Org. Chem. 2007, 72, 9357.

10. Distilled THF always contains some amount of moisture. This provides partial (hydrated $\mathrm{Cu}$ and Co salts) and good $\left(\mathrm{FeCl}_{3}\right)$ solubility of the metal salts in it and facilitates bimetal redox reactions as well as subsequent $\mathrm{C}-\mathrm{C}$ bond forming reactions (Scheme 1). It has been observed that in anhydrous THF none of the earlier reactions ${ }^{9 \mathrm{a}-\mathrm{c}}$ took place apparently due to very poor solubility of these metal salts.

11. (a) Chattopadhyay, A.; Mamdapur, V. R. J. Org. Chem. 1995, 60, 585. (b) Chattopadhyay, A. J. Org. Chem. 1996, 61, 6104.

12. Reddy, C. K.; Periasamy, M. Tetrahedron 1993, 39, 8877.

13. In general, syn-5a could be identified from its ${ }^{13} \mathrm{C}$ signals of the mixture of $\mathbf{5 a}$ and $\mathbf{5 b}$ at all regions appearing consistently at more downfield compared to the corresponding signals of anti-5b. This could be evident from the fact that following oxidation of this isomeric mixture and K-selectride reduction of 6 (ref 15), the downfield signals of syn-5a enhanced very much. Hence, by determining the ratio of ${ }^{13} \mathrm{C}$ signals of $\mathbf{5 a}, \mathbf{b}$, their relative proportion in a diasterisomeric mixture could be estimated. This could be evident from the ${ }^{13} \mathrm{C}-\mathrm{NMR}$ spectra 
of 5a,b mixtures obtained after low valent $\mathrm{Cu}$ mediated benzylation, benzyl Grignard addition and K-selectride reduction that was shown in the Supporting Information.

14. Sato, F. Y. ; Kobayashi, Y.; Takahashi, O. ; Chiba, T.; Takeda, Y.; Kusukabe, M. J. Chem.. Soc. Chem.. Commun. 1985, 1636.

15. Dhotare, B.; Salaskar, A.; Chattopadhyay, A. Synthesis 2003, 2571.

16. (a) Izaw, K.; Onishi, T. Chem. Rev. 2006, 106, 2827. (b) Park, S. ; Lee, S.; Kang, H-J. Bull Korean Chem. Soc. 2008, 29, 1073. (c). Ghosh, A. K ; Bilcer, G.; Sciltz, G. Synthesis 2001, 2203 and references cited therein. (d) Ghosh, A. K. ; McKee, S. P.; Lee, H. Y. ; Thompson, W. J. J. Chem. Soc. Chem. Commun. 1992, 273. (e) Ghosh, A. K. ; Thompson, W. J.; Holloway, M. K.; McKee, S. P.; Duong, T. T.; Lee, H. Y. ; Munson, P. M.; Smith, A. M.; Wei, J. M. ; Dark, P. L. ; Zugay, J. A. J. Med. Chem., 1993, 36, 2300.

17. Caron, M.; Carlier, P. R. ; Sharpless, K. B. J. Org. Chem. 1988, 53, 5187. 